\title{
Downregulation of Bid is associated with PKC $\varepsilon$-mediated TRAIL resistance
}

\author{
U Sivaprasad ${ }^{1,2,3}$, E Shankar ${ }^{1,2,3}$ and A Basu ${ }^{\star, 1,2}$
}

Tumor necrosis factor-related apoptosis-inducing ligand (TRAIL) is a promising anticancer agent as it selectively kills tumor cells but spares normal cells. Resistance to TRAIL by tumor cells limits its therapeutic use. We have previously shown that protein kinase C- $\varepsilon$ (PKC $\varepsilon)$ acts as an antiapoptotic protein in MCF-7 breast cancer cells. In the present study, we have investigated the mechanism(s) by which PKC $\varepsilon$ contributes to TRAIL resistance. Overexpression of PKC $\varepsilon$ inhibited caspase-8 and -9 activation, release of mitochondrial cytochrome $c$ and cell death induced by TRAIL, but did not interfere with the recruitment of caspase-8 to the death-inducing signaling complex. Knockdown/inhibition of PKC $\varepsilon$ resulted in enhanced sensitivity to TRAIL. The level of Bcl-2 was increased and Bid was decreased by PKC $\varepsilon$ at both the protein and mRNA level but PKC $\varepsilon$ had no effect on Bax. Knockdown of Bcl-2 by siRNA reversed TRAIL resistance in PKC $\varepsilon$-overexpressing cells, whereas depletion of Bid contributed to TRAIL resistance in MCF-7 cells. A decrease in Bid content was also associated with inhibition of TRAIL-induced caspase-8 activation. Furthermore, PKC $\varepsilon$ depletion or overexpression of DN-PKC $\varepsilon$ was associated with a decrease in $\mathrm{Bcl}-2$ protein level. Thus, our results suggest that PKC $\varepsilon$ acts upstream of mitochondria and mediates TRAIL resistance via both Bcl-2 and Bid in MCF-7 cells.

Cell Death and Differentiation (2007) 14, 851-860. doi:10.1038/sj.cdd.4402077; published online 22 December 2006

Tumor necrosis factor-related apoptosis-inducing ligand (TRAIL), a member of the tumor necrosis factor- $\alpha$ (TNF) superfamily, induces apoptosis in a variety of tumor cells with minimal toxicity to normal cells. ${ }^{1}$ Thus, TRAIL is particularly valuable for cancer therapy. Resistance to TRAIL-mediated apoptosis by tumor cells, however, limits its therapeutic use. ${ }^{2,3}$ An understanding of the mechanism(s) of TRAIL resistance is essential to improve its application in cancer therapy.

TRAIL-mediated apoptosis involves ligand-dependent trimerization of TRAIL receptors DR4 or DR5, and the recruitment and activation of the death-inducing signaling complex (DISC) composed of Fas-associated death domain (FADD) and initiator procaspase-8. ${ }^{4-6}$ Active caspase-8 subsequently cleaves and activates the effector caspase-3 and -7 , ultimately resulting in apoptosis. ${ }^{4,5}$ Depending on the cell type, TRAIL can also amplify cell death through the mitochondrial pathway. ${ }^{7}$ Cross-talk between the receptormediated pathway and mitochondria occurs when active caspase- 8 cleaves Bid and the truncated Bid translocates to the mitochondria causing activation of Bax/Bak, release of cytochrome $c$ and activation of caspases. ${ }^{8-11}$ Downregulation/mutations in caspase-8 or increased expression of FLIP can contribute to TRAIL resistance..$^{3,12-15}$ The presence of antiapoptotic proteins, such as Akt or Bcl-2 family members can also contribute to TRAIL resistance by affecting either the extrinsic or the intrinsic cell death pathway. ${ }^{2,10,15-18}$

Protein kinase $C$ (PKC), a family of phospholipid-dependent serine/threonine kinases, is emerging as a critical regulator of cellular responses to TRAIL. ${ }^{12,14,18-24}$ The PKC family consists of 11 isoforms that are classified as conventional $(\alpha, \beta 1, \beta 2$ and $\gamma)$, novel $(\delta, \varepsilon, \eta$ and $\theta)$ or atypical $(\zeta$ and $l / \lambda){ }^{25}$ $\mathrm{PKCs}$ are involved in the regulation of cell proliferation, differentiation as well as cell death. ${ }^{26} \mathrm{PKC} \varepsilon$ is the only PKC isoform that has been reported to have oncogenic potential. $^{27,28}$ There is also considerable evidence that $\mathrm{PKC} \varepsilon$ acts as an antiapoptotic protein. ${ }^{23,29,30}$

Activation of PKC was shown to protect against TRAILinduced apoptosis in several cell lines, including cervical cancer, multiple myeloma, glioma and breast cancer. $^{19,20,22,23}$ There are conflicting reports as to the mechanisms by which PKC exerts its protective effect. In cervical cancer HeLa cells, PKC activation hindered apical events in the TRAIL receptor-mediated pathway by interfering with FADD recruitment to the DISC. ${ }^{20}$ PKC inhibitors inhibited FLIP and clAP-2 expression in multiple myeloma cells. ${ }^{12,14}$ In melanoma and breast cancer MCF-7 cells, PKC acted upstream of mitochondria but downstream of caspase-8 and Bid. ${ }^{19,22}$ In the latter study, the effect of phorbol myristic acetate (PMA) was examined but the contribution of a specific PKC isoform was not tested. The mechanism of

\footnotetext{
${ }^{1}$ Department of Molecular Biology and Immunology, University of North Texas Health Science Center, Fort Worth, TX, USA and ${ }^{2}$ Institute for Cancer Research, Fort Worth, TX, USA

${ }^{*}$ Corresponding author: A Basu, Department of Molecular Biology and Immunology, University of North Texas Health Science Center, 3500 Camp Bowie Boulevard, Fort Worth, TX 76107, USA. Tel: + 1817735 2487; Fax: + 1817735 2118; E-mail: abasu@ hsc.unt.edu

${ }^{3}$ Both authors contributed equally.

Keywords: PKC $\varepsilon$; TRAIL; Bcl-2; Bid; apoptosis; breast cancer

Abbreviations: DISC, death-inducing signaling complex; DN, dominant-negative; MTT, 3-4,5-dimethylthiazol-2-yl-2,5-diphenyltetrazolium bromide; PARP, poly(ADPribose) polymerase; PKC, protein kinase C; PI, propidium iodide; PMA, phorbol myristic acetate; SDS-PAGE, sodium dodecyl sulfate-polyacrylamide gel electrophoresis; $\mathrm{t}$-Bid, truncated-Bid; TNF, tumor necrosis factor- $\alpha$; TRAIL, TNF-related apoptosis-inducing ligand

Received 10.7.06; revised 11.10.06; accepted 31.10.06; Edited by GM Cohen; published online 22.12.06
} 
TRAIL resistance may vary depending on the PKC isozyme. $^{14,18,19,24,31}$

PKC $\varepsilon$ has been implicated in inhibiting TRAIL-induced apoptosis in glioma and melanoma cells. ${ }^{18,19,23}$ Increased levels and activity of $\mathrm{PKC} \varepsilon$ were associated with TRAIL resistance, ${ }^{19}$ and overexpression of $\mathrm{PKC} \varepsilon$ inhibited TRAILinduced apoptosis in these cells. ${ }^{18,23}$ It has been reported that cellular susceptibility to TRAIL cannot be explained by the status of TRAIL receptor expression but does correlate with $\mathrm{PKC} \varepsilon$ level. ${ }^{23}$ Furthermore, $\mathrm{PKC} \varepsilon$ overexpression did not modify the cell surface expression of TRAIL receptors in erythromyeloid cell lines. ${ }^{21}$ It has been reported that mitochondria constitute an important target in overcoming inherent resistance to TRAIL. 2,3,10,16,19,22,32 However, PKC $\varepsilon$ did not affect Bcl-2 and Bax in glioma cells. ${ }^{18}$ Thus, the mechanisms underlying the protective effect of $\mathrm{PKC} \varepsilon$ and its regulation of components of the mitochondrial pathway in TRAIL-induced cell death are incompletely understood.

We have previously reported that $\mathrm{PKC} \varepsilon$ protects MCF-7 breast cancer cells against receptor-initiated apoptosis. ${ }^{30}$ In this study, we have examined the mechanism(s) of the antiapoptotic effect of PKC $\varepsilon$ in TRAIL-induced cell death. We report for the first time that $\mathrm{PKC} \varepsilon$ inhibited TRAIL-mediated apoptosis by simultaneously increasing $\mathrm{Bcl}-2$ and decreasing Bid expression in MCF-7 cells. Additionally, a decrease in Bid was associated with inhibition of TRAIL-induced caspase-8 activation. These results explain how $\mathrm{PKC} \varepsilon$ could inhibit TRAIL-induced apoptosis by acting upstream of mitochondria at the level of Bid and $\mathrm{Bcl}-2$.

\section{Results}

Overexpression of PKC $\varepsilon$ delays TRAIL-induced cell death. We have previously shown that $\mathrm{PKC} \varepsilon$ protects cells against TNF-induced cell death in MCF-7 cells. ${ }^{30} \mathrm{We}$ determined whether $\mathrm{PKC} \varepsilon$ overexpression would exert a protective effect against TRAIL-induced apoptosis. MCF-7 cells overexpressing $\mathrm{PKC} \varepsilon$ (MCF-7/PKC $\varepsilon$ ) or vectortransfected control cells (MCF-7/Neo) were treated with different concentrations of TRAIL, and cell viability was determined by the 3-4,5-dimethylthiazol-2-yl-2,5-diphenyltetrazolium bromide (MTT) assay. Figure 1a revealed that the $\mathrm{IC}_{50}$ of TRAIL for MCF-7/Neo cells $(0.027 \mathrm{nM})$ was almost eightfold less than MCF-7/PKC $\varepsilon$ cells $(0.16 \mathrm{nM})$. The $\mathrm{IC}_{50}$ of TRAIL for MCF-7/Neo cells was equivalent to untransfected MCF-7 cells $(0.021 \mathrm{nM}$, data not shown). As MCF-7 cells transfected with the empty vector can control for any nonspecific effect associated with transfection and G418 selection, we primarily used MCF-7/Neo cells instead of MCF-7 cells for comparison with MCF-7/PKC $\varepsilon$ cells.

MCF-7 cells lack caspase- 3 and therefore they do not undergo DNA fragmentation or exhibit characteristic morphological features of apoptosis, such as chromatin condensation. ${ }^{33}$ Poly(ADP-ribose) polymerase (PARP) is a substrate for both caspase-3 and -7, and the cleavage of full-length 116$\mathrm{kDa}$ PARP to the $85-\mathrm{kDa}$ cleaved form is a convenient way to monitor cell death. Figure $1 \mathrm{~b}$ shows that TRAIL induced a concentration-dependent increase in PARP cleavage; the 85$\mathrm{kDa}$ cleavage product of PARP was evident when MCF-7/Neo cells were treated with $0.03 \mathrm{nM}$ TRAIL. We have tested two different stable clones of MCF-7 cells expressing $\mathrm{PKC} \varepsilon$ and both clones exhibited resistance to TRAIL-induced cell death. Unless otherwise mentioned, we have used clone 1 in all subsequent experiments and these cells are designated as MCF-7/PKC $\varepsilon$. Overexpression of $\mathrm{PKC} \varepsilon$ decreased TRAILinduced PARP cleavage and a 10-fold higher concentration of TRAIL was necessary to cause equivalent PARP cleavage in MCF-7/PKC $\varepsilon$ cells. In contrast, $0.01 \mathrm{nM}$ TRAIL was sufficient to induce PARP cleavage in MCF-7 cells expressing dominant-negative $\mathrm{PKC} \varepsilon$.

We also examined the effect of PKC overexpression on the time course of PARP cleavage. As shown in Figure 1c, PARP cleavage in MCF-7/Neo cells was evident at $6 \mathrm{~h}$ of treatment with TRAIL, whereas MCF-7/PKC $\varepsilon$ cells exhibited a delayed response to TRAIL, with PARP cleavage evident at $18 \mathrm{~h}$ of treatment. As prolonged treatment with TRAIL may cause further cleavage of PARP, it is sometime difficult to demonstrate a time-dependent increase in cleaved PARP. The levels of full-length PARP in TRAIL-treated MCF-7/PKC $\varepsilon$ cells were greater compared to MCF-7/Neo cells. Thus, overexpression of $\mathrm{PKC} \varepsilon$ in $\mathrm{MCF}-7$ cells delayed TRAILinduced cell death.

We also examined the effect of $\mathrm{PKC} \varepsilon$ overexpression on the clonogenic survival. As shown in Figure 1d, treatment of vector-transfected cells with $0.1 \mathrm{nM}$ TRAIL caused a substantial decrease in colony formation, such that 37 and $10 \%$ colonies survived when MCF-7/Neo cells were treated with TRAIL for 10 and $20 \mathrm{~h}$, respectively. In contrast, similar treatment of MCF-7/PKC $\varepsilon$ with TRAIL decreased clonogenic survival only to 76 and $67 \%$. These results suggest that $\mathrm{PKC} \varepsilon$ protected MCF-7 cells from loss of clonogenic survival induced by TRAIL.

Overexpression of $\mathrm{PKC} \varepsilon$ does not affect TRAIL receptor expression and caspase- 8 recruitment to the DISC. As binding of TRAIL to its receptors causes recruitment of FADD and caspase- 8 to form DISC resulting in activation of caspase-8, we examined if overexpression of $\mathrm{PKC} \varepsilon$ interferes with the recruitment of caspase-8 to the DISC. Figure 2 shows that $\mathrm{PKC} \varepsilon$ overexpression had no effect on the levels of DR4 and DR5. In addition, the abundance of FADD and caspase-8 associated with the DISC did not decrease by $\mathrm{PKC} \varepsilon$ overexpression. A slight decrease in procaspase-8 in the DISC of MCF-7/Neo cells compared to MCF-7/PKC $\varepsilon$ could be due to processing of procaspase-8 during $30 \mathrm{~min}$ incubation with $500 \mathrm{ng} / \mathrm{ml}$ TRAIL to generate the cleaved fragment. These results suggest that a decrease in caspase-8 recruitment to the DISC was not responsible for TRAIL resistance of MCF-7/PKC $\varepsilon$ cells.

Overexpression of PKC $\varepsilon$ inhibits TRAIL-induced caspase activation. Although TRAIL primarily acts through the receptor-initiated pathway, it can also amplify cell death through the mitochondrial pathway. ${ }^{7}$ We therefore examined the effect of $\mathrm{PKC} \varepsilon$ on TRAIL-induced activation of apical caspase- 8 and -9 of the extrinsic and intrinsic pathway, respectively (Figure 3). Treatment of MCF-7/Neo cells with TRAIL caused a concentration-dependent increase in processing of both procaspase- 8 and -9 . MCF-7 cells do 
a
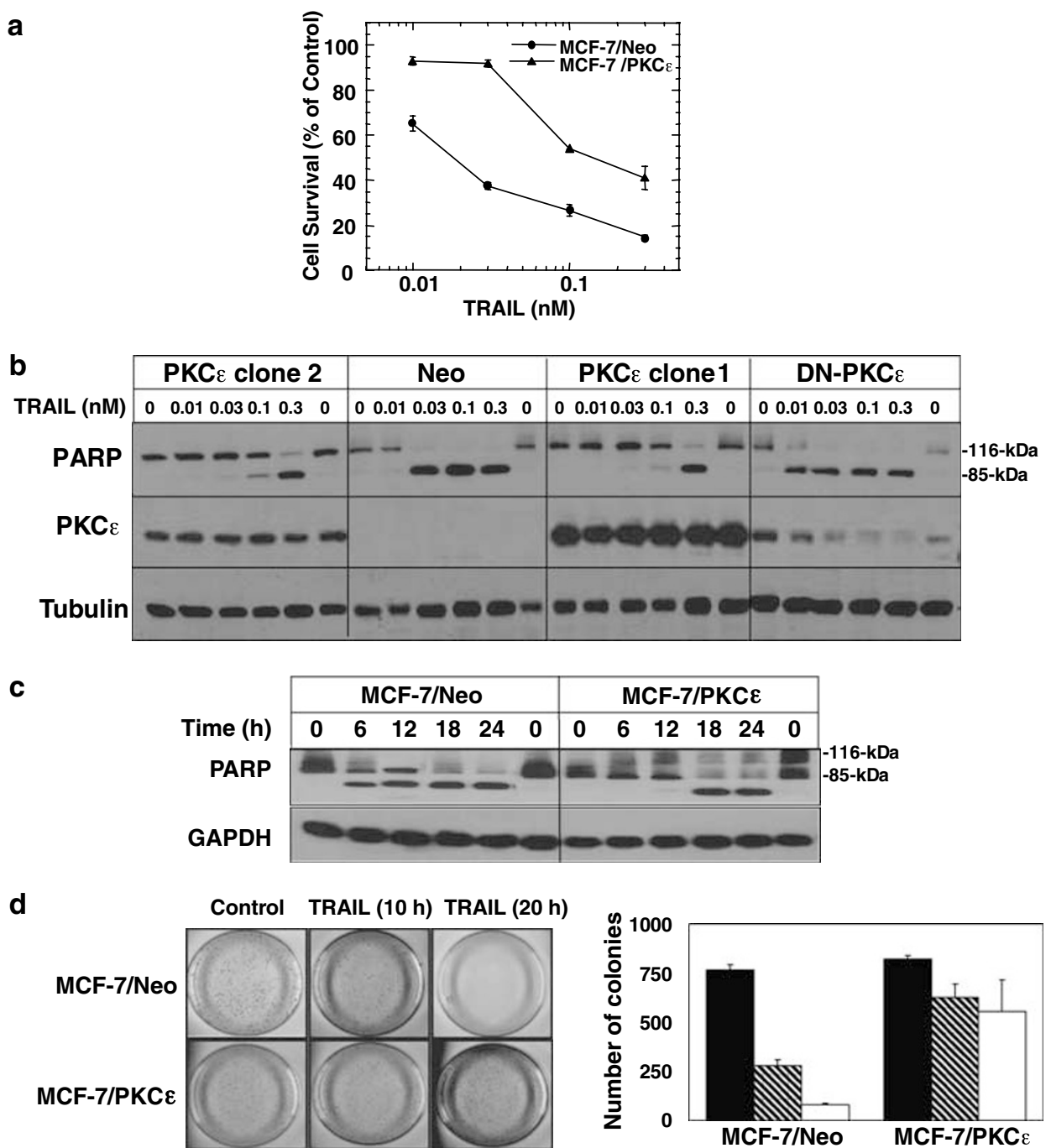

Figure 1 Time-course and concentration-response of TRAIL-induced cell death in MCF-7/Neo and MCF-7/PKC $\varepsilon$ cells. (a) Cells were treated with the indicated concentrations of TRAIL for $48 \mathrm{~h}$. Cell viability was determined by the MTT assay as described in Materials and Methods. Data are the mean \pm S.E.M. of three separate experiments. (b) Cells were treated with varying concentrations of TRAIL for $10 \mathrm{~h}$, and Western blot analysis was performed with total cell lysates using the indicated antibodies. Tubulin was used as the loading control. (c) Cells were treated with $0.1 \mathrm{nM}$ TRAIL for the indicated periods of time, and Western blot analysis was performed with total cell lysates using the indicated antibodies. GAPDH was used as the loading control. (d) Cells were treated without (solid bar) or with $0.1 \mathrm{nM} \mathrm{TRAIL} \mathrm{for} 10 \mathrm{~h}$ (hatched bar) or $20 \mathrm{~h}$ (open bar) and clonogenic assay was performed as described in Materials and Methods. The results are representative of two independent experiments. The bar graph represents average colonies \pm S.D. of duplicate plates
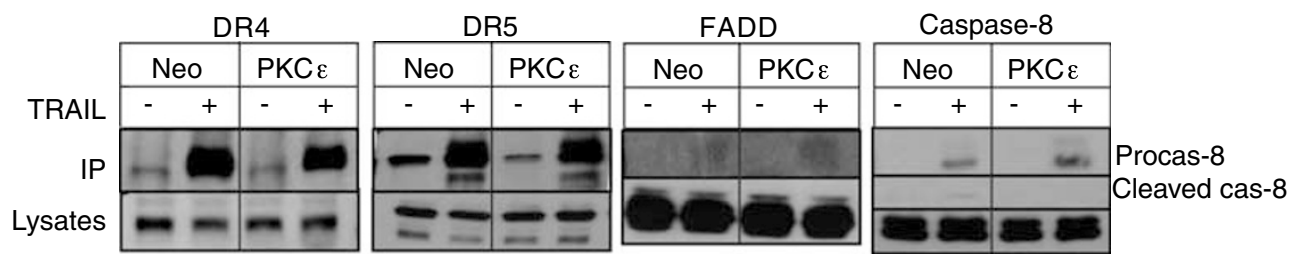

Figure 2 Effect of PKC $\varepsilon$ overexpression on the recruitment of caspase-8 and FADD to TRAIL receptors. MCF-7/Neo and MCF-7/PKC $\varepsilon$ cells were treated with or without FLAG-TRAIL for $30 \mathrm{~min}$ and DISCs were immunoprecipitated as described in Materials and Methods. Western blot analyses were performed with the indicated antibodies. The results are representative of two independent experiments

not express functional caspase-3, but the activation of effector caspase-7 and -6 was increased by TRAIL treatment. $\mathrm{PKC} \varepsilon$ overexpression attenuated TRAIL-induced activation of both apical caspase- 8 and -9 , as well as downstream effector caspase-6 and -7 (Figure 3). Thus, $\mathrm{PKC} \varepsilon$ not only affects the extrinsic cell death pathway but also suppresses signaling through the intrinsic or mitochondrial cell death pathway. 


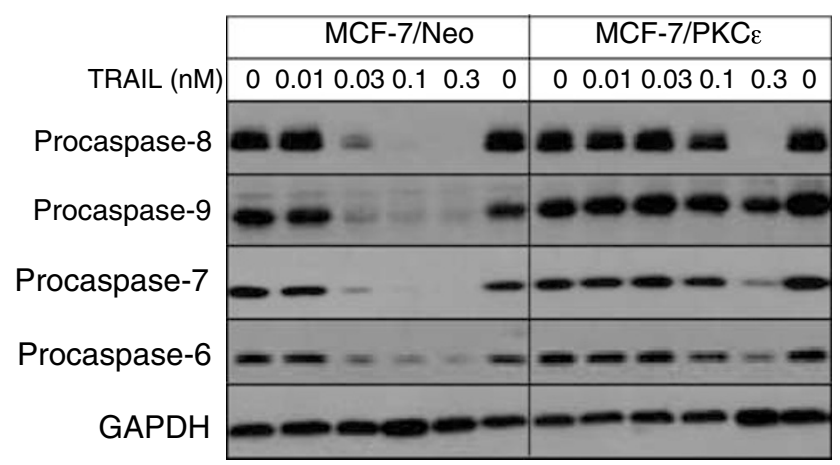

Figure 3 Overexpression of PKC $\varepsilon$ inhibits TRAIL-induced caspase activation. MCF-7/Neo and MCF-7/PKC $\varepsilon$ cells were treated with varying concentrations of TRAIL for $10 \mathrm{~h}$ and Western blot analysis was performed with total cell lysates using the indicated antibodies. GAPDH was used as the loading control
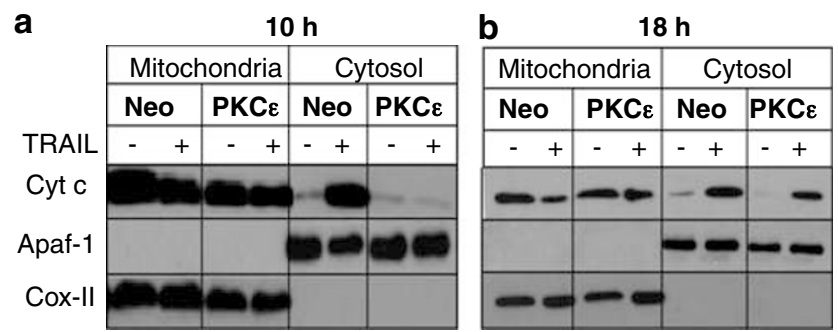

Figure 4 Overexpression of $\mathrm{PKC} \varepsilon$ inhibits TRAIL-induced cytochrome $c$ release. MCF-7/Neo and MCF-7/PKC $\varepsilon$ cells were treated with $0.3 \mathrm{nM}$ TRAIL for (a) $10 \mathrm{~h}$ and (b) $18 \mathrm{~h}$. Cells were fractionated into cytosol and heavy membrane fraction enriched in mitochondria and Western blot analysis was performed with the indicated antibodies. Cytochrome oxidase subunit 2 and Apaf-1 were used as mitochondrial and cytosolic markers, respectively

Overexpression of $\mathrm{PKC} \varepsilon$ inhibits TRAlL-induced cytochrome $c$ release. Cytochrome $c$ release is a critical event in the mitochondrial cell death pathway. We therefore examined the effect of $\mathrm{PKC} \varepsilon$ overexpression on TRAILinduced cytochrome $c$ release from the mitochondria. Heavy membrane enriched in mitochondria and cytosolic fractions were isolated from MCF-7/Neo and MCF-7/PKC $\varepsilon$ cells after treatment with $0.3 \mathrm{nM}$ TRAIL for 10 (Figure $4 \mathrm{a}$ ) or $18 \mathrm{~h}$ (Figure 4b). Treatment of MCF-7/Neo cells with TRAIL caused an increase in cytochrome $c$ in the cytosol. Overexpression of PKC $\varepsilon$ in MCF-7 cells prevented TRAILinduced cytochrome $c$ release when treated with TRAIL for $10 \mathrm{~h}$ (Figure 4a). However, when cells were treated with $0.3 \mathrm{nM}$ TRAIL for $18 \mathrm{~h}$, we could detect cytochrome $c$ release in MCF-7/PKC $\varepsilon$ cells although the extent of cytochrome $c$ release was less compared to MCF-7/Neo cells (Figure 4b). The level of Apaf-1, a cytosolic protein, was not affected by TRAIL treatment. Cytochrome oxidase subunit 2, a mitochondrial marker, was detected only in the mitochondrial fraction. These results suggest that $\mathrm{PKC} \varepsilon$ overexpression inhibits the mitochondrial cell death pathway by inhibiting release of cytochrome $c$ from the mitochondria.

Overexpression of $\mathrm{PKC} \varepsilon$ upregulates $\mathrm{Bcl}-2$ and downregulates Bid expression. As Bcl-2 family proteins regulate the mitochondrial cell death pathway, we compared levels of the Bcl-2 family proteins in MCF-7/Neo and MCF-7/ $\mathrm{PKC} \varepsilon$ cells. As shown in Figure $5 \mathrm{a}$, the level of $\mathrm{Bcl}-2$ was increased whereas the level of Bid was decreased in two stable clones of MCF-7 cells overexpressing PKC $\varepsilon$ compared to MCF-7/Neo cells. Based on densitometric scanning of several independent experiments, there was a 2.5 -fold increase in Bcl-2 $(P<0.05)$ and a 3.3-fold decrease in Bid $(P<0.05)$ in MCF-7/PKC $\varepsilon$ cells compared to MCF-7/Neo cells (Figure $5 b$ ). Reverse transcriptase-polymerase chain reaction (RT-PCR) analysis of RNA isolated from these cell lines also revealed an increase in $\mathrm{BCl}-2$ and a decrease in Bid mRNA in MCF-7/PKC $\varepsilon$ cells (Figure $5 \mathrm{c}$ ). Similar results were obtained when two different primers were used during RTPCR. The proteasome inhibitor MG132 had no effect on the decrease in Bid in MCF-7/PKC $\varepsilon$ cells (data not shown). These results suggest that $\mathrm{PKC} \varepsilon$ regulates $\mathrm{Bid}$ and $\mathrm{Bcl}-2$ at the level of transcription. However, levels of Bax mRNA and protein were equivalent in both cell lines. Thus, an increase in the ratio of antiapoptotic Bcl-2 to proapoptotic Bid may contribute to TRAIL resistance in MCF-7/PKC $\varepsilon$ cells. $\mathrm{PKC} \varepsilon$ overexpression did not decrease the levels of other antiapoptotic proteins, such as X-linked inhibitor of apoptosis (XIAP) or c-FLIP (Figure $5 d$ ).

Depletion of Bid inhibits TRAIL-induced apoptosis in MCF-7 cells. To determine the functional significance of Bid downregulation in MCF-7/PKC $\varepsilon$ cells, we overexpressed Bid in MCF-7/PKC $\varepsilon$ cells. The transfection efficiency of Bid plasmid in MCF-7/PKC $\varepsilon$ was low (7-8\%) and overexpression of Bid in MCF-7/PKC $\varepsilon$ cells by itself caused cell death (Figure 6). Therefore, we were unable to isolate stable clones. Nevertheless, these results suggest that overexpression of Bid can reverse antiapoptotic effect of $\mathrm{PKC} \varepsilon$. We then depleted Bid using siRNA and determined cell death in response to TRAIL. Figure $7 a$ shows that knockdown of Bid by siRNA selectively decreased Bid but not $\mathrm{Bcl}-2$ or Bax. Depletion of Bid resulted in protection from TRAIL-induced cleavage of PARP in MCF-7 (Figure 7b) as well as MCF-7/Neo cells (Figure 7c). The effect of untransfected cells was similar to control siRNA-transfected cells (data not shown). We also stained cells with Annexin VAlexa 488 conjugate and propidium iodide $(\mathrm{PI})$ to monitor apoptosis. As shown in Figure 8, 0.1 nM TRAIL increased cell death to $72 \%$ in both untransfected and control siRNAtransfected MCF-7 cells. Knockdown of Bid inhibited TRAIL-induced apoptosis in MCF-7 cells to $12 \%$. These results suggest that a decrease in proapoptotic Bid in MCF-7/ $\mathrm{PKC} \varepsilon$ cells may contribute to TRAIL resistance.

Treatment with TRAIL also resulted in the cleavage of Bid and the truncated Bid (t-Bid) was visible in TRAIL-treated MCF-7 (Figure 7b) or MCF-7/Neo cells (Figure 7c). Interestingly, depletion of Bid by siRNA was associated with a decrease in the cleavage of full-length Bid (Figure $7 b$ and $c$ ). As Bid is cleaved by caspase-8, we examined the effect of Bid knockdown on caspase-8 processing. Figure $7 \mathrm{~b}$ shows that depletion of Bid inhibited processing of not only procaspase- 9 but also of procaspase-8.

Depletion of Bcl-2 potentiates TRAIL-induced apoptosis in MCF-7 cells. We also examined the consequence of 
a

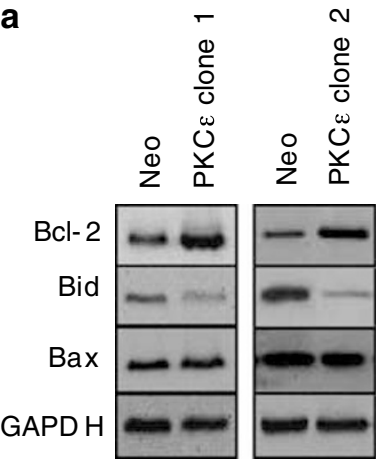

b

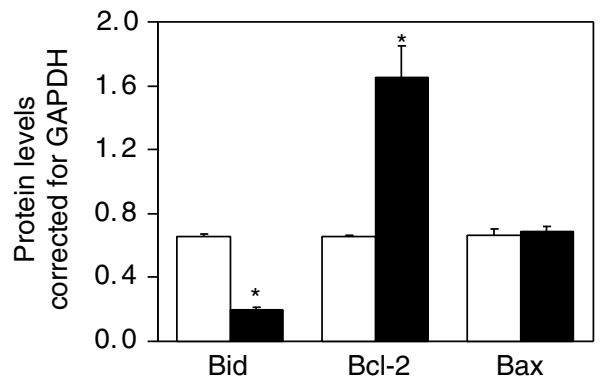

d
C

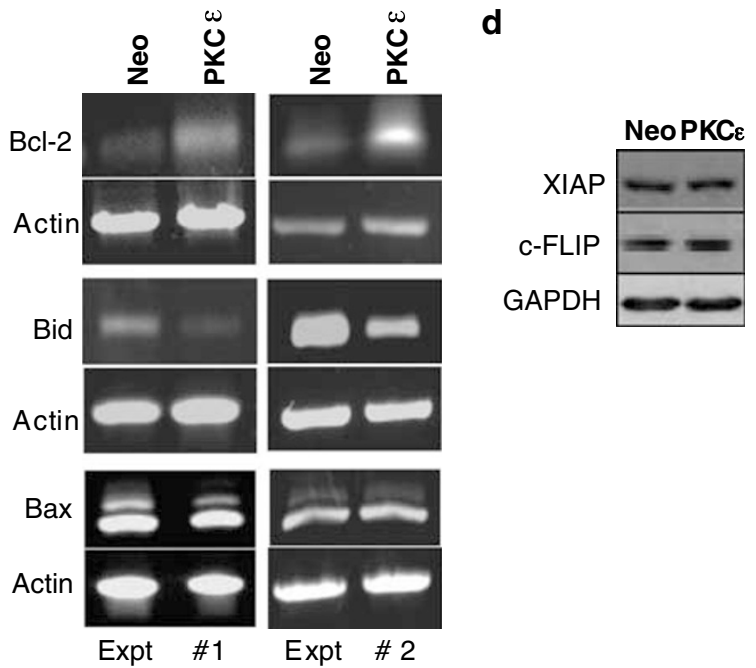

Figure 5 Overexpression of PKC $\varepsilon$ upregulates Bcl-2 and downregulates Bid. (a) Total cell extracts from MCF-7/Neo and MCF-7/PKC $\varepsilon$ cells were analyzed by Western blot analysis with the indicated antibodies. GAPDH was used to control for loading differences. (b) Densitometric quantification of three separate experiments corrected for loading. Data are the mean \pm S.E.M. Asterisks indicate a significant difference from MCF-7/Neo cells $(P<0.05)$ using paired Student's $t$-test. Open bar, MCF-7/Neo; closed bar, MCF-7/PKC $\varepsilon$. (c) RT-PCR analysis was performed for detecting Bid, Bcl-2, Bax and actin expression. The results are representative of three independent experiments. Two experiments with two different primers are shown. (d) Western blot analysis of total cell lysates was performed with the indicated antibodies. GAPDH was used to control for loading differences

TRAIL (nM) 0 0.1

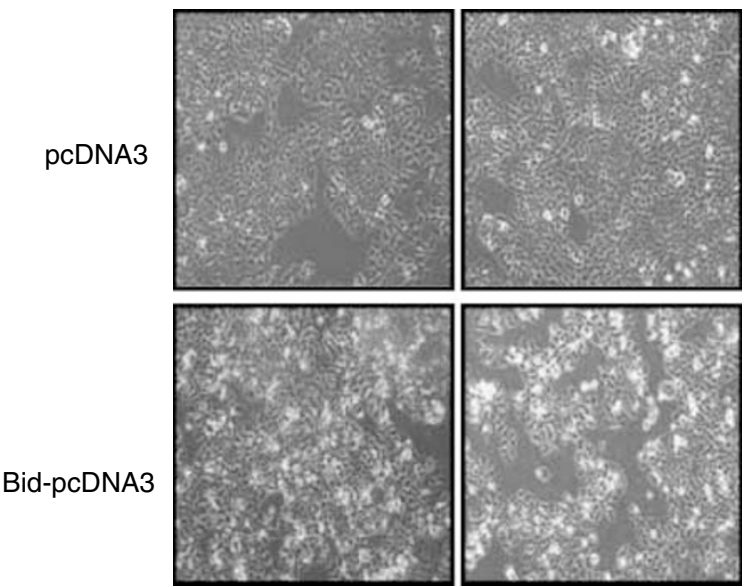

Figure 6 Effect of Bid overexpression on cell death. MCF-7/PKC $\varepsilon$ cells were transfected with empty vector or vector containing Bid as described under Materials and Methods. After $24 \mathrm{~h}$ of transfection, cells were treated with $0.1 \mathrm{nM}$ TRAIL for $8 \mathrm{~h}$ and cellular morphology was examined under a microscope. The results are representative of two independent experiments
Bcl-2 depletion on TRAIL-induced cell death in MCF-7 cells. Knockdown of Bcl-2 decreased the level of $\mathrm{Bcl}-2$ but not of Bid (Figure 9a) or Bax (data not shown). Depletion of Bcl-2 in MCF-7 cells enhanced TRAIL-induced cell death as evident by the cleavage of PARP (Figure 9a) and by Annexin V/PI staining (Figure 8). Although $0.01 \mathrm{nM}$ TRAIL had little effect on cell death in untransfected or control siRNAtransfected MCF-7 cells, it caused $35 \%$ cell death in Bcl-2depleted cells (Figure 8). However, Bcl-2 knockdown had no additional effect on cell death in MCF-7 and MCF-7/Neo cells treated with 0.1 or $1.0 \mathrm{nM}$ TRAIL (Figures $8,9 \mathrm{a}$ and b). Knockdown of Bcl-2 also enhanced TRAIL-induced activation of caspase- 8 and -9 as well as cleavage of Bid in MCF-7 cells (Figure 9a). As MCF-7/PKC $\varepsilon$ cells overexpressed $\mathrm{Bcl}-2$, we also examined if depletion of $\mathrm{Bcl}-$ 2 would reverse TRAIL resistance in these cells. Knockdown of $\mathrm{Bcl}-2$ restored the sensitivity of $\mathrm{MCF}-7 / \mathrm{PKC} \varepsilon$ cells to TRAIL as judged by PARP cleavage (Figure 9b) and Annexin $\mathrm{V}$ dye binding assay (Figure $9 \mathrm{c}$ ). Thus, upregulation of $\mathrm{Bcl}-2$ may contribute to TRAIL resistance in $\mathrm{PKC} \varepsilon$-overexpressing cells. 
a

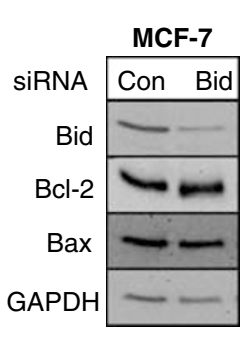

b

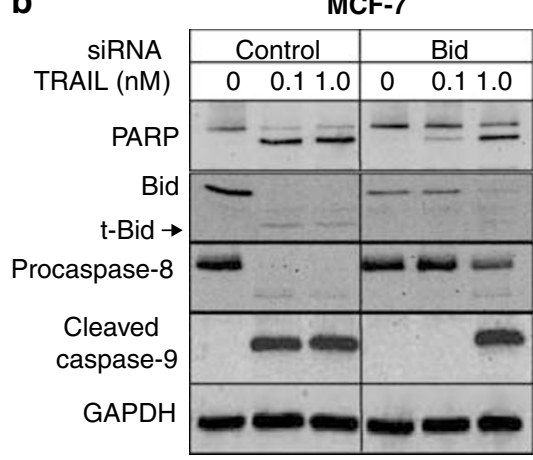

c

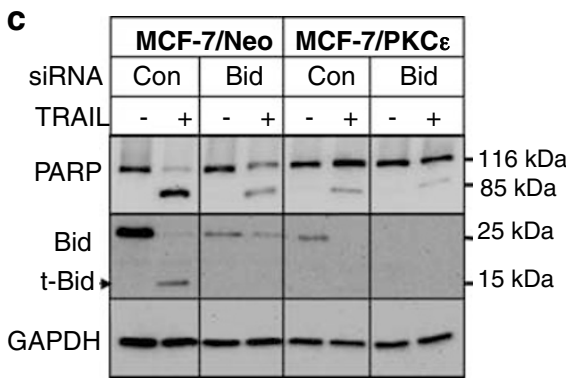

Figure 7 Depletion of Bid attenuates TRAIL-mediated PARP cleavage, caspase activation and cell death. (a) Western blot analysis was performed with total cell lysates from MCF-7 cells treated with control or Bid siRNA. (b) Bid was depleted from MCF-7 cells using siRNA. Cells were then treated with or without $0.1 \mathrm{nM}$ or $1.0 \mathrm{nM}$ TRAIL for $10 \mathrm{~h}$. Western blot analysis was performed with the indicated antibodies. (c) MCF-7/Neo and MCF-7/PKC $\varepsilon$ cells transfected with control or Bid siRNA were treated with or without $1.0 \mathrm{nM}$ TRAIL for $10 \mathrm{~h}$. Western blot analysis was performed with the indicated antibodies. GAPDH was used to control for loading differences. The results are representative of three independent experiments

Knockdown of PKC $\varepsilon$ increases TRAIL sensitivity. To further examine the link between $\mathrm{Bcl}-2$, Bid and the antiapoptotic function of $\mathrm{PKC} \varepsilon$, we depleted $\mathrm{PKC} \varepsilon$ by siRNA. Figure 10 shows that knockdown of PKC $\varepsilon$ by siRNA enhanced cellular sensitivity to TRAIL as determined by activation of caspase-8 and -9, PARP cleavage (Figure 10a) and Annexin $V$ dye binding assay (Figure 10b). Although TRAIL (0.01 nM) had little effect on cell death in untransfected and control siRNA-transfected MCF-7 cells, it caused approximately $70 \%$ cell death in $\mathrm{PKC} \varepsilon$-depleted cells (Figure 10b). Knockdown of $\mathrm{PKC} \varepsilon$ decreased Bcl-2 level (Figure 10c). Based on densitometric scanning of three independent experiments, $\mathrm{PKC} \varepsilon$ depletion was associated with a 2.2-fold decrease in $\mathrm{Bcl}-2$. $\mathrm{PKC} \varepsilon$ knockdown caused only a modest increase in Bid (Figure 10c). Expression of dominant-negative $\mathrm{PKC} \varepsilon$ also caused a similar decrease in $\mathrm{Bcl}-2$ and an increase in Bid (Figure 10d). Thus, although the levels of both $\mathrm{Bcl}-2$ and Bid are important determinants of $\mathrm{PKC} \varepsilon$-mediated TRAIL resistance, decrease in $\mathrm{Bcl}-2$ may be primarily responsible for TRAIL sensitization in PKC $\varepsilon-$ depleted cells.

\section{Discussion}

The ability of TRAIL to kill cancer cells is counteracted by the presence of antiapoptotic proteins, contributing to TRAIL resistance. In the present study, we have investigated the mechanism(s) by which $\mathrm{PKC} \varepsilon$ contributes to TRAIL resistance. Our results show that an increase in antiapoptotic Bcl-2 and a decrease in proapoptotic Bid were associated with PKC $\varepsilon$-mediated TRAIL resistance in MCF-7 cells.

There have been several reports that suggest that PKC acts upstream of the mitochondrial pathway to regulate cell death by TRAIL, although the site of action of PKC $\varepsilon$ in the cell death pathway is not well established. ${ }^{18,19,22,23}$ The mitochondrial cell death pathway is regulated by the interaction between pro- and antiapoptotic members of the Bcl-2 family. Several studies have implicated Bax as an important mediator of cellular responsiveness to TRAIL. ${ }^{16,34,35}$ Bax-deficient colon cancer cells were resistant to TRAIL-induced apoptosis. ${ }^{2}$ Bax, but not Bak, sensitized leukemic and prostate cancer cells to TRAIL. ${ }^{35,36}$ PKC $\varepsilon$-deficient LNCaP cells were sensitive to PMA-induced apoptosis and forced expression of $\mathrm{PKC} \varepsilon$ in these cells conferred resistance to PMA-mediated apoptosis via interaction with Bax. ${ }^{34}$ We have shown that the levels of antiapoptotic $\mathrm{Bcl}-2$ as well as proapoptotic Bid were regulated by PKC $\varepsilon$ in MCF-7 breast cancer cells, whereas PKC $\varepsilon$ had no effect on the level of Bax. It has been reported that EPOdriven upregulation of $\mathrm{PKC} \varepsilon$ level renders differentiating erythroid cells resistant to TRAIL likely via $\mathrm{Bcl}-2$ upregulation. $^{21}$ We have shown that overexpression of $\mathrm{PKC} \varepsilon$ increased Bcl-2 not only at the protein level but also at the mRNA level. In addition, knockdown of $\mathrm{PKC}_{\varepsilon}$ by siRNA decreased $\mathrm{Bcl}-2$ level. Furthermore, depletion of $\mathrm{Bcl}-2$ by siRNA reversed the antiapoptotic effect of PKC $\varepsilon$. Taken together, these results provide direct evidence that $\mathrm{Bcl}-2$ is involved in the antiapoptotic function of $\mathrm{PKC} \varepsilon$ in MCF-7 breast carcinoma cells. Depletion of Bcl-2 not only enhanced TRAILinduced activation of caspase- 9 but also of caspase-8. As caspase- 8 can also be cleaved by effector caspases, such as caspase- 6 , activation of caspase- 8 could be a consequence of TRAIL-induced activation of caspase-9. Although MCF-7 cells do not express caspase- 3 , which is believed to cleave caspase-6, ${ }^{37}$ TRAIL did induce processing of caspase- 6 in MCF-7 cells and PKC $\varepsilon$ inhibited cleavage of procaspase- 6 .

It is generally believed that the antiapoptotic effect of PKC $\varepsilon$ occurs downstream of caspase-8 activation and Bid cleavage. ${ }^{18,19,21,22,38}$ We also found that overexpression of PKC $\varepsilon$ did not alter the levels of TRAIL receptors or interfere with the recruitment of caspase-8 to the DISC. Overexpression of $\mathrm{PKC} \varepsilon$ caused a decrease in Bid protein and mRNA in MCF-7 cells. Consequently, the level of truncated Bid in response to TRAIL treatment was also lower in $\mathrm{PKC} \varepsilon$-overexpressing cells. However, depletion of $\mathrm{PKC}_{\varepsilon}$ caused only a slight increase in Bid level. It is conceivable that although overexpression of $\mathrm{PKC} \varepsilon$ represses Bid transcription, a decrease in constitutive level of $\mathrm{PKC} \varepsilon$ had no effect on Bid expression. Alternatively, as Bid is cleaved when cells undergo apoptosis and depletion of PKC $\varepsilon$ alone induces cell death, it may be difficult to demonstrate increase in Bid following depletion of $\mathrm{PKC} \varepsilon$. Consistent with this notion, we have found that overexpression of Bid not only induced cell death in $\mathrm{PKC} \varepsilon$ overexpressing cells (Figure 6 ), but also resulted in cleavage of Bid (data not shown). We do not know if forced expression of Bid results in mitochondrial localization causing release of cytochrome $\mathrm{c}$ and activation of caspases resulting in cleavage 


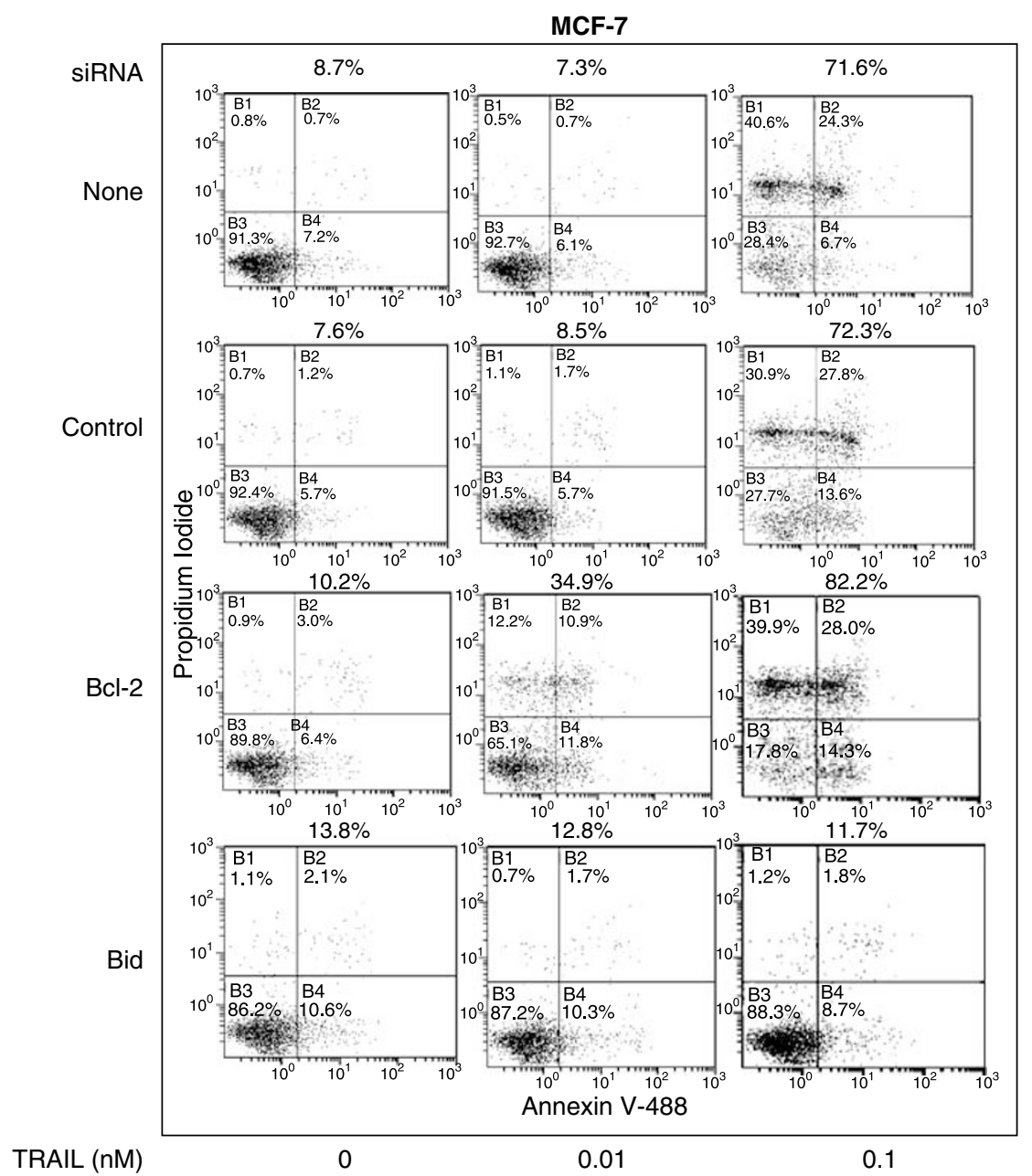

Figure 8 Depletion of Bcl-2 or Bid affects TRAIL resistance in MCF-7 cells. MCF-7 cells were transfected with or without control, Bcl-2 or Bid siRNA and then treated with the indicated concentrations of TRAIL for $10 \mathrm{~h}$. Cells were stained with Annexin V-Alexa 488 conjugate and PI and analyzed by flow cytometry. The results are representative of two independent experiments

of Bid. In addition, knockdown of Bid by siRNA decreased TRAIL sensitivity in MCF-7 cells, suggesting the importance of Bid in regulating TRAIL sensitivity in these cells.

Overexpression of $\mathrm{PKC} \varepsilon$ in MCF-7 cells caused inhibition of caspase- 8 and -9 processing in response to TRAIL. The effect of $\mathrm{PKC} \varepsilon$ on caspase-8 activation may be a consequence of the decrease in Bid expression. We have shown that knockdown of Bid in fact inhibited TRAIL-induced cleavage of Bid and activation of caspase-8. Thus, Bid is not only a substrate for caspase- 8 but it can also regulate its activation. We propose that in response to TRAIL, activation of caspase- 8 results in cleavage of Bid and translocation of $t$-Bid to mitochondria, resulting in release of cytochrome $c$, activation of caspase- 9 and cell death. This cross-talk drives more caspase- 8 cleavage by a feed-forward mechanism. As the level of Bid is decreased by $\mathrm{PKC} \varepsilon$ overexpression, the level of $\mathrm{t}$-Bid generated by TRAIL-induced activation of casapse- 8 is less in $\mathrm{PKC} \varepsilon$-overexpressing cells. As $\mathrm{PKC} \varepsilon$ also induces antiapoptotic $\mathrm{Bcl}-2$, the ratio of antiapoptotic and proapoptotic $\mathrm{Bcl}-2$ family members is increased further. Inhibition of the mitochondrial cell death pathway results in a decrease in Bid cleavage and inhibition of TRAIL-induced caspase-8 activation.

TRAIL is a highly promising candidate for the treatment of cancer because it exhibits selective cytotoxicity to cancer cells. Some tumor cells, however, evade TRAIL-induced apoptosis owing to the presence of antiapoptotic proteins. It has been reported that tumor cells that overexpress $\mathrm{PKC} \varepsilon$ are resistant to TRAIL. ${ }^{19,23}$ The elucidation of the mechanism of TRAIL resistance is highly significant for its effective application in the clinic. We provide direct evidence that both $\mathrm{Bcl}-2$ and Bid are important for PKC $\varepsilon$-mediated TRAIL resistance. Thus, $\mathrm{Bcl}-2$ family proteins could be targeted to reverse TRAIL resistance in breast cancer cells.

\section{Materials and Methods}

Reagents. Human recombinant TRAIL and polyclonal antibody to caspase-8 were purchased from R\&D systems (Minneapolis, MN, USA). Human recombinant FLAG-TRAIL, monoclonal antibody to anti-FLAG and polyclonal antibodies to DR4 and DR5 were obtained from Axxora LLC (San Diego, CA, USA). Monoclonal antibody to Bcl-2, glyceraldehyde-3-phosphate dehydrogenase (GAPDH), c-FLIP and polyclonal antibody to $\mathrm{PKC} \varepsilon$ were purchased from Santa Cruz Biotechnology, 


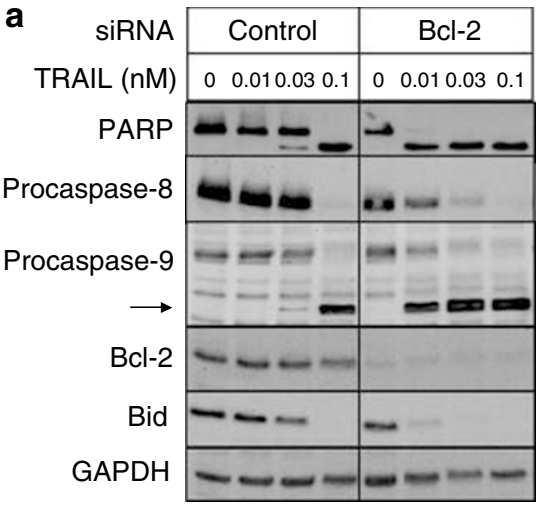

b

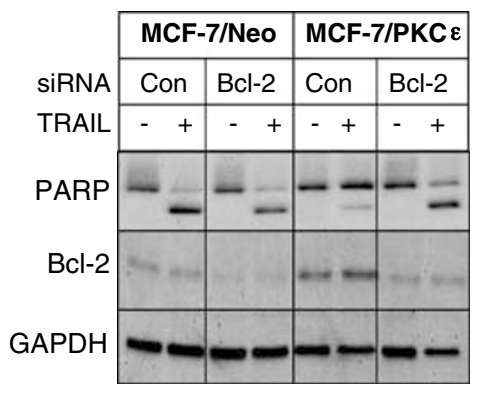

C

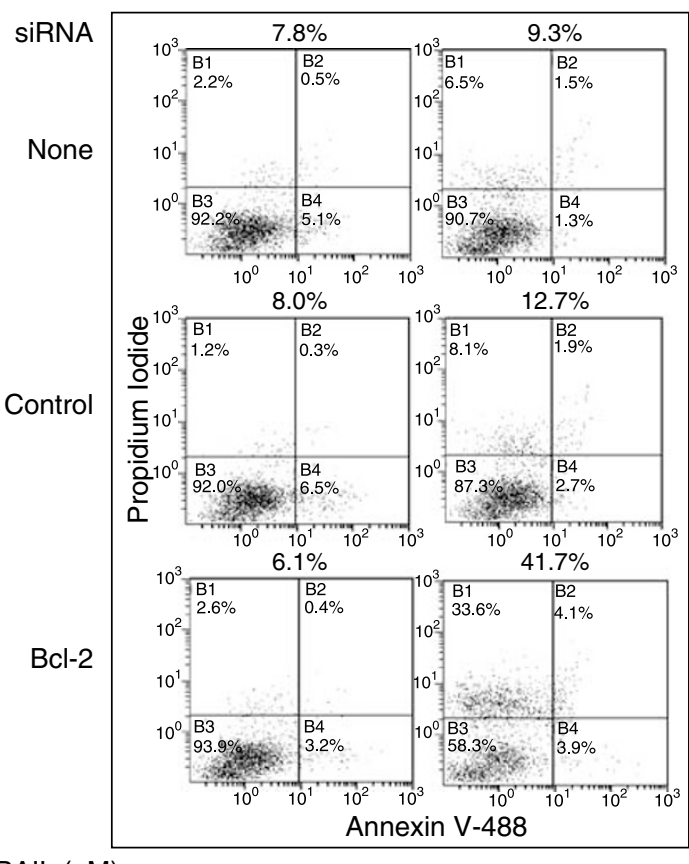

TRAIL (nM)

$+$

Figure 9 Depletion of Bcl-2 abrogates TRAIL resistance in MCF-7/PKC $\varepsilon$ cells. (a) MCF-7 cells were transfected with control siRNA or siRNA targeted against Bcl-2. Cells were then treated with the indicated concentrations of TRAIL for $10 \mathrm{~h}$. Western blot analysis was performed with the indicated antibodies. GAPDH was used to control for loading differences. (b) MCF-7/Neo and MCF-7/PKC $\varepsilon$ cells were transfected with control or Bcl-2 siRNA and then treated with $1.0 \mathrm{nM} \mathrm{TRAIL} \mathrm{for} 10 \mathrm{~h}$. Western blot analysis was performed with the indicated antibodies. GAPDH was used to control for loading differences. (c) MCF-7/PKC $\varepsilon$ cells were transfected with or without control or Bcl-2 siRNA and then treated with $0.1 \mathrm{nM}$ TRAIL for $10 \mathrm{~h}$. Cells were then stained with Annexin V-Alexa 488 conjugate and PI, and analyzed by flow cytometry. The results are representative of two independent experiments

Inc. (Santa Cruz, CA, USA). Polyclonal antibody to Bid and monoclonal antibody to caspase-8 were purchased from BioSource (Camarillo, CA, USA). Monoclonal antibody to PARP, XIAP, FADD, caspase-7 and polyclonal antibody to caspase-9 were purchased from Pharmingen (San Diego, CA, USA). Polyclonal antibody to caspase-6 was obtained from Cell Signaling Technologies (Beverly, MA, USA). MTT and crystal violet were purchased from Sigma (St Louis, MO, USA). siRNA SMARTpool against PKC $\varepsilon, \mathrm{Bcl}-2$, Bid and nontargeting SMARTpool siRNA were obtained from Dharmacon (Lafayette, CO, USA). Annexin V-Alexa 488 and PI were obtained from Molecular Probes (Eugene, OR, USA). Horseradish peroxidaseconjugated goat anti-mouse and donkey anti-rabbit antibodies were obtained from Jackson ImmunoResearch (West Grove, PA, USA). The enhanced chemiluminescence detection kit was from Amersham (Arlington Heights, IL, USA).

Cell culture and transfection. MCF-7 cells were maintained in RPMI 1640 medium supplemented with $10 \%$ heat-inactivated fetal bovine serum and $2 \mathrm{~mm}$ glutamine and kept in a humidified incubator at $37^{\circ} \mathrm{C}$ with $95 \%$ air and $5 \% \mathrm{CO}_{2}$. MCF-7/Neo, MCF-7/PKC $\varepsilon$ and MCF-7/DN-PKC $\varepsilon$ cells were generated as described previously. ${ }^{30}$ MCF-7/PKC $\varepsilon$ cells were co-transfected with either $2 \mu \mathrm{g}$ of empty vector or Bid-pcDNA3. 1 together with $2 \mu \mathrm{g} \mathrm{SV40-} \beta$-gal plasmids using Fugene HD reagent (Roche Biomedicals) according to the manufacturer's instructions. Transfection efficiency was determined by $\beta$-galactosidase expression.

Knockdown of $\mathrm{PKC} \varepsilon$ and $\mathrm{Bcl}-2$ family members. siRNAs against $\mathrm{PKC} \varepsilon, \mathrm{Bcl}-2$, Bid or nontargeting SMARTpool were introduced into MCF-7 cells using lipofectamine 2000 (Invitrogen) according to the manufacturer's protocol. Briefly, cells were seeded one day before transfection. Lipofectamine 2000 and siRNA diluted in Opti-minimal essential medium (MEM) were mixed gently at a ratio of $300 \mathrm{ng}$ lipofectamine $2000: 133 \mathrm{ng}$ siRNA and incubated at room temperature for $15-20 \mathrm{~min}$. Culture medium was replaced with Opti-MEM and $100 \mu \mathrm{l}$ of siRNA:lipofectamine 2000 complexes were added to cells. After 4-6h, fresh culture medium was added to cells. After $48 \mathrm{~h}$, following siRNA transfection, cells were treated with TRAIL.
Assessment of cell viability by MTT assay. Exponentially growing MCF-7, MCF-7/Neo and MCF-7/PKC $\varepsilon$ cells were plated in microtiter plates and incubated in a humidified incubator at $37^{\circ} \mathrm{C}$ with $5 \% \mathrm{CO}_{2}$. The following day, cells were treated with or without different concentrations of TRAIL as described in the text and incubated for $48 \mathrm{~h}$. The number of viable cells was determined using the dye MTT.

Clonogenic assay. MCF-7/Neo or MCF-7/PKC $\varepsilon$ cells were seeded in 10-cm tissue culture dish and allowed to attach overnight. Cells were treated with or without $0.1 \mathrm{nM}$ TRAIL for the indicated periods. Following incubation, the media were replaced with fresh media. Cells were then incubated in a humidified incubator at $37^{\circ} \mathrm{C}$ and $5 \% \mathrm{CO}_{2}$ until there were at least 50 cells per colony in untreated cells. At the end of the incubation, cells were washed with phosphate-buffered saline (PBS) and incubated with a $0.25 \%$ crystal violet solution for $15 \mathrm{~min}$. Colonies were counted using the colony-counting tool in the BioChemi System (UVP).

RT-PCR analysis. Total RNA was isolated using RNA STAT-60 from Tel-Test Inc, (Friendswood, TX, USA), as per the manufacturer's protocol and subjected to RT reaction using Promega (Madison, WI, USA) reverse transcriptase enzyme (ImProm-IIM). PCR amplifications were performed using the following primers: Bax, forward, 5'-GGC CCA CCA GCT CTG AGC AGA TCA T-3'; reverse, 5'-CCT GGT CTT GGA TCC AGC CCA ACA G-3'. BCl-2, forward, 5'-TAT AAG CTG TCG CAG AGG GGC TA-3'; reverse, $5^{\prime}$-GTA CTC AGT CAT CCA CAG GGC GAT-3' and forward, 5' GAC AGT CCC ATC AAA ACT CC 3'; reverse, 5' ATG ATC AGG TCC TTT TTC CA $3^{\prime}$. Bid, forward, $5^{\prime}$-ATG GAC TGT GAG GTC AAC GGC GC-3'; reverse, 5'-CCC GGC CAG AAA TGG GAT GGA CT-3' and forward, 5' GCA TGT CAA CAG CGT TCC TA $3^{\prime}$; reverse: $5^{\prime}$ GGA ACC TGC ACA GTG GAA AT $3^{\prime}$. Actin, forward, 5'-TAC AAT GAG CTG CGT GTG GCT-3'; reverse, 5'-ATC CAC ATC TGC TGG AAG GTG GA-3'. Cycle conditions for all PCRs were set up for 40 cycles as follows: denaturation at $95^{\circ} \mathrm{C}$ for $1 \mathrm{~min}$, annealing at $55^{\circ} \mathrm{C}$ for $1 \mathrm{~min}$, extension at $72^{\circ} \mathrm{C}$ for $1 \mathrm{~min}$ and final extension at $72^{\circ} \mathrm{C}$ for $10 \mathrm{~min}$. The products were resolved on a $1 \%$ agarose gel containing ethidium bromide. 
a

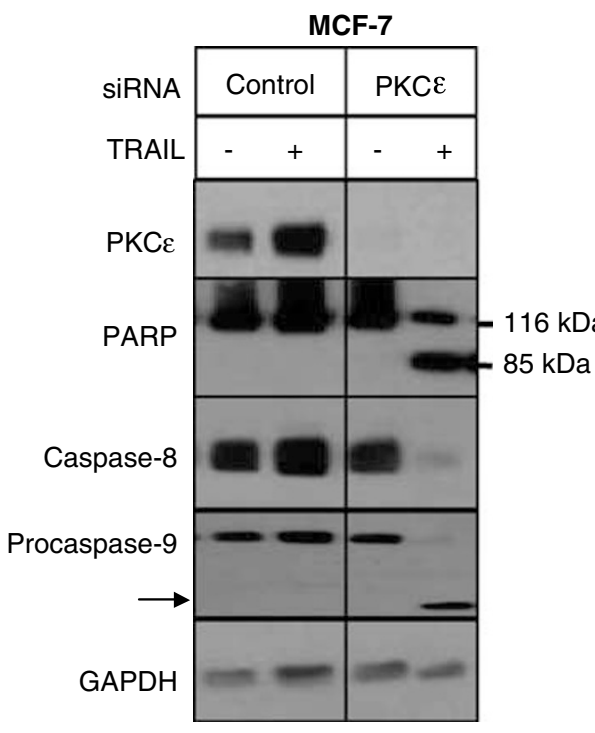

C

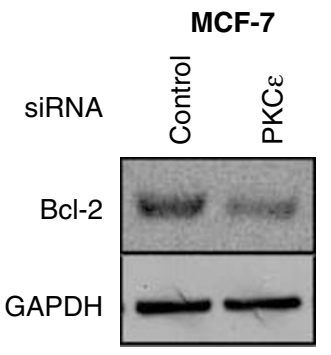

b

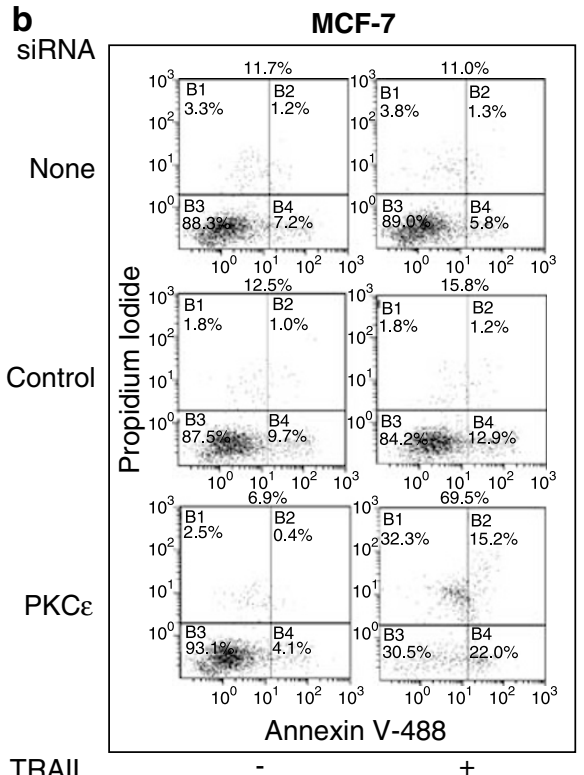

TRAIL

d
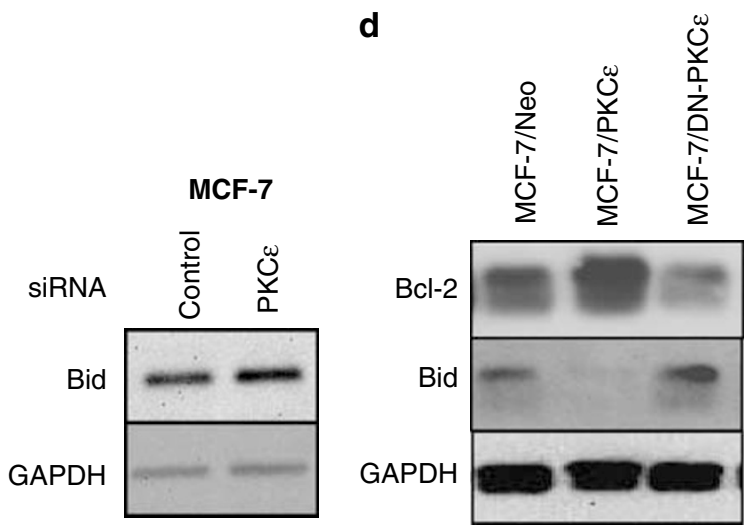

Figure 10 Depletion of PKC $\varepsilon$ increases TRAIL sensitivity. (a) MCF-7 cells transfected with control siRNA or siRNA targeted against PKC $\varepsilon$ were treated with $0.01 \mathrm{nM}$ TRAIL for $10 \mathrm{~h}$. Western blot analysis was performed with the indicated antibodies and GAPDH was used as the loading control. (b) MCF-7 cells transfected with or without control siRNA or siRNA targeted against PKC $\varepsilon$ were treated with $0.01 \mathrm{nM}$ TRAIL for $10 \mathrm{~h}$. Cells were stained with Annexin V-Alexa 488 conjugate and PI, and analyzed by flow cytometry. The results are representative of two independent experiments. (c) MCF-7 cells were transfected with control siRNA or siRNA targeted against PKC $\varepsilon$. Cell lysates were analyzed by Western blotting with Bcl-2 or Bid antibody. GAPDH was used to control for loading differences. Results are representative of three independent experiments. (d) Cell lysates from MCF-7/Neo, MCF-7/PKC $\varepsilon$ and MCF-7/DN-PKC $\varepsilon$ were analyzed by Western blotting with the indicated antibodies. Results are representative of two independent experiments

Preparation of cytosolic and mitochondrial extracts. Following treatment with or without TRAIL, cells were collected, washed twice with PBS and subcellular fractionation was performed as described previously. ${ }^{39}$

Immunoblot analysis. Equivalent amounts of protein from total cellular extracts were electrophoresed by sodium dodecyl sulfate-polyacrylamide gel electrophoresis (SDS-PAGE) and transferred electrophoretically to polyvinylidene difluoride membrane. Immunoblot analyses were performed as described previously. ${ }^{39}$

DISC analysis. Analysis of DISC formation was performed as described previously ${ }^{40}$ with some modifications. Briefly, cells were treated with $500 \mathrm{ng} / \mathrm{ml}$ human recombinant soluble FLAG-tagged TRAIL and $1.5 \mu \mathrm{g} / \mathrm{ml}$ anti-FLAG monoclonal antibody (enhancer) for $30 \mathrm{~min}$. Cells were lysed in $20 \mathrm{~mm} \mathrm{Tris}-\mathrm{HCl}$, $\mathrm{pH} 7.4,0.15 \mathrm{M} \mathrm{NaCl}, 1 \mathrm{mM}$ EDTA, $1 \%$ TX-100, 0.5\% NP-40, $25 \mathrm{~mm} \beta$ glycerophosphate, $10 \mathrm{~mm} \mathrm{NaF}, 1.0 \mathrm{~mm} \mathrm{Na}_{3} \mathrm{VO}_{4}$ and protease inhibitor cocktail, and protein complexes were precipitated by incubation with protein $A / G$ agarose. Beads were washed four times with immunoprecipitation buffer and denatured by boiling in Laemmli buffer containing $\beta$-mercaptoethanol. Proteins were separated by SDS-PAGE and Western blot analyses were performed.

Annexin V/PI-binding assay. Cells were treated with or without TRAIL. At the end of the incubation, both detached cells and attached cells were collected and washed with PBS. Cells were then stained with Annexin V-Alexa 488 conjugate and $\mathrm{PI}$ according to the manufacturer's protocol and analyzed using a flow cytometer (Coulter Epics).

Acknowledgements. This work was supported by the grant CA71727 (AB) from the $\mathrm{NCl}$. We thank Dr Sandra Zinkel for providing us Bid plasmid and Jose Mireles for technical assistance.

1. Pitti RM, Marsters SA, Ruppert S, Donahue CJ, Moore A, Ashkenazi A. Induction of apoptosis by Apo-2 ligand, a new member of the tumor necrosis factor cytokine family. J Biol Chem 1996; 271: 12687-12690. 
2. LeBlanc $\mathrm{H}$, Lawrence D, Varfolomeev E, Totpal K, Morlan J, Schow $\mathrm{P}$ et al. Tumor-cell resistance to death receptor - induced apoptosis through mutational inactivation of the proapoptotic Bcl-2 homolog Bax. Nat Med 2002; 8: 274-281.

3. Zhang L, Fang B. Mechanisms of resistance to TRAIL-induced apoptosis in cancer. Cancer Gene Ther 2005; 12: 228-237.

4. Kischkel FC, Hellbardt S, Behrmann I, Germer M, Pawlita M, Krammer PH et al. Cytotoxicity-dependent APO-1 (Fas/CD95)-associated proteins form a death-inducing signaling complex (DISC) with the receptor. EMBO J 1995; 14: 5579-5588.

5. Pan G, O'Rourke K, Chinnaiyan AM, Gentz R, Ebner R, Ni J et al. The receptor for the cytotoxic ligand TRAIL. Science 1997; 276: 111-113

6. Sprick MR, Weigand MA, Rieser E, Rauch CT, Juo P, Blenis J et al. FADD/MORT1 and caspase- 8 are recruited to TRAIL receptors 1 and 2 and are essential for apoptosis mediated by TRAIL receptor 2. Immunity 2000; 12: 599-609.

7. Scaffidi C, Fulda S, Srinivasan A, Friesen C, Li F, Tomaselli KJ et al. Two CD95 (APO-1/ Fas) signaling pathways. EMBO J 1998; 17: 1675-1687.

8. Eskes R, Desagher S, Antonsson B, Martinou JC. Bid induces the oligomerization and insertion of Bax into the outer mitochondrial membrane. Mol Cell Biol 2000; 20: 929-935.

9. Gross A, Yin XM, Wang K, Wei MC, Jockel J, Milliman C et al. Caspase cleaved BID targets mitochondria and is required for cytochrome $c$ release, while $B C L-X L$ prevents this release but not tumor necrosis factor-R1/Fas death. J Biol Chem 1999; 274: 1156-1163.

10. Rudner J, Jendrossek V, Lauber K, Daniel PT, Wesselborg S, Belka C. Type I and type II reactions in TRAIL-induced apoptosis - results from dose-response studies. Oncogene 2005; 24: 130-140.

11. Wang $\mathrm{K}$, Yin XM, Chao DT, Milliman CL, Korsmeyer SJ. BID: a novel BH3 domain-only death agonist. Genes Dev 1996; 10: 2859-2869.

12. Mitsiades N, Mitsiades CS, Poulaki V, Anderson KC, Treon SP. Intracellular regulation of tumor necrosis factor-related apoptosis-inducing ligand-induced apoptosis in human multiple myeloma cells. Blood 2002; 99: 2162-2171.

13. van Geelen CM, de Vries EG, Le TK, van Weeghel RP, de Jong S. Differential modulation of the TRAIL receptors and the CD95 receptor in colon carcinoma cell lines. $\mathrm{Br} J$ Cancer 2003; 89: 363-373

14. Wang $Q$, Wang $X$, Zhou Y, Evers BM. PKC delta-mediated regulation of FLIP expression in human colon cancer cells. Int J Cancer 2006; 118: 326-334.

15. Nam SY, Jung GA, Hur GC, Chung HY, Kim WH, Seol DW et al. Upregulation of FLIP(S) by Akt, a possible inhibition mechanism of TRAlL-induced apoptosis in human gastric cancers. Cancer Sci 2003; 94: 1066-1073.

16. He Q, Montalbano J, Corcoran C, Jin W, Huang Y, Sheikh MS. Effect of Bax deficiency on death receptor 5 and mitochondrial pathways during endoplasmic reticulum calcium poo depletion-induced apoptosis. Oncogene 2003; 22: 2674-2679.

17. Kim KM, Song JJ, An JY, Kwon YT, Lee YJ. Pretreatment of acetylsalicylic acid promotes tumor necrosis factor-related apoptosis-inducing ligand-induced apoptosis by downregulating BCL-2 gene expression. J Biol Chem 2005; 280: 41047-41056.

18. Okhrimenko H, Lu W, Xiang C, Hamburger N, Kazimirsky G, Brodie C. Protein kinase Cepsilon regulates the apoptosis and survival of glioma cells. Cancer Res 2005; 65: 73017309.

19. Gillespie $S$, Zhang XD, Hersey $P$. Variable expression of protein kinase $C$ epsilon in human melanoma cells regulates sensitivity to TRAIL-induced apoptosis. Mol Cancer Ther 2005; 4: $668-676$.

20. Harper N, Hughes MA, Farrow SN, Cohen GM, MacFarlane M. Protein kinase C modulates tumor necrosis factor-related apoptosis-inducing ligand-induced apoptosis by targeting the apical events of death receptor signaling. J Biol Chem 2003; 278: 4433844347.

21. Mirandola P, Gobbi G, Ponti C, Sponzilli I, Cocco L, Vitale M. PKC epsilon controls protection against TRAIL in erythroid progenitors. Blood 2006; 107: 508-513.
22. Sarker M, Ruiz-Ruiz C, Robledo G, Lopez-Rivas A. Stimulation of the mitogen-activated protein kinase pathway antagonizes TRAIL-induced apoptosis downstream of BID cleavage in human breast cancer MCF-7 cells. Oncogene 2002; 21: 4323-4327.

23. Shinohara H, Kayagaki N, Yagita H, Oyaizu N, Ohba M, Kuroki T et al. A protective role of PKC epsilon against TNF-related apoptosis-inducing ligand (TRAIL)-induced apoptosis in glioma cells. Biochem Biophys Res Commun 2001; 284: 1162-1167.

24. Sonnemann J, Gekeler V, Sagrauske A, Muller C, Hofmann HP, Beck JF. Down-regulation of protein kinase $C$ eta potentiates the cytotoxic effects of exogenous tumor necrosis factorrelated apoptosis-inducing ligand in PC-3 prostate cancer cells. Mol Cancer Ther 2004; 3 : 773-781.

25. Nishizuka Y. Intracellular signalling by hydrolysis of phospholipids and activation of protein kinase C. Science 1992; 258: 607-613.

26. Basu A. Involvement of PKC- $\delta$ in DNA damage-induced apoptosis. J Cell Mol Med 2003; 7 341-350.

27. Cacace AM, Guadagno SN, Krauss RS, Fabbro D, Weinstein IB. The epsilon isoform of protein kinase $C$ is an oncogene when overexpressed in rat fibroblasts. Oncogene 1993; 8 2095-2104.

28. Perletti GP, Concari P, Brusaferri S, Marras E, Piccinini F, Tashjian Jr AH. Protein kinase C epsilon is oncogenic in colon epithelial cells by interaction with the ras signal transduction pathway. Oncogene 1998; 16: 3345-3348.

29. Basu A, Cline JS. Oncogenic transformation alters cisplatin-induced apoptosis in rat embryo fibroblasts. Int J Cancer 1995; 63: 597-603.

30. Basu A, Lu D, Sun B, Moor AN, Akkaraju GR, Huang J. Proteolytic activation of protein kinase $\mathrm{C}$-epsilon by caspase-mediated processing and transduction of antiapoptotic signals. J Biol Chem 2002; 277: 41850-41856.

31. Okhrimenko H, Lu W, Xiang C, Ju D, Blumberg PM, Gomel R et al. Roles of tyrosine phosphorylation and cleavage of protein kinase $C \backslash\{$ deltal\} in its protective effect against tumor necrosis factor-related apoptosis inducing ligand-induced apoptosis. J Biol Chem 2005; 280: 23643-23652.

32. Tillman DM, Izeradjene K, Szucs KS, Douglas L, Houghton JA. Rottlerin sensitizes colon carcinoma cells to tumor necrosis factor-related apoptosis-inducing ligand-induced apoptosis via uncoupling of the mitochondria independent of protein kinase C. Cancer Res 2003; 63: 5118-5125.

33. Janicke RU, Sprengart ML, Wati MR, Porter AG. Caspase-3 is required for DNA fragmentation and morphological changes associated with apoptosis. J Biol Chem 1998 273: 9357-9360.

34. McJilton MA, Van Sikes C, Wescott GG, Wu D, Foreman TL, Gregory CW et al. Protein kinase $\mathrm{C}$-epsilon interacts with Bax and promotes survival of human prostate cancer cells. Oncogene 2003; 22: 7958-7968.

35. Wendt J, von Haefen C, Hemmati P, Belka C, Dorken B, Daniel PT. TRAIL sensitizes fo ionizing irradiation-induced apoptosis through an entirely Bax-dependent mitochondrial cell death pathway. Oncogene 2005; 24: 4052-4064.

36. Han J, Goldstein LA, Gastman BR, Rabinovitz A, Wang GQ, Fang B et al. Differentia involvement of Bax and Bak in TRAIL-mediated apoptosis of leukemic T cells. Leukemia 2004; 18: 1671-1680.

37. Slee EA, Harte MT, Kluck RM, Wolf BB, Casiano CA, Newmeyer DD et al. Ordering the cytochrome $c$-initiated caspase cascade: hierarchical activation of caspases-2, -3, -6, -7, -8 , and -10 in a caspase-9-dependent manner. J Cell Biol 1999; 144: 281-292.

38. Gubina E, Rinaudo MS, Szallasi Z, Blumberg PM, Mufson RA. Overexpression of protein kinase $C$ isoform epsilon but not delta in human interleukin-3-dependent cells suppresses apoptosis and induces bcl-2 expression. Blood 1998; 91: 823-829.

39. Basu $A$, Woolard MD, Johnson CL. Involvement of protein kinase $\mathrm{C}$-delta in DNA damageinduced apoptosis. Cell Death Differ 2001; 8: 899-908.

40. Bodmer JL, Holler N, Reynard S, Vinciguerra P, Schneider P, Juo P et al. TRAIL receptor-2 signals apoptosis through FADD and caspase-8. Nat Cell Biol 2000; 2: 241-243. 